\title{
PERBEDAAN KEMAMPUAN PEMAHAMAN KONSEP MATEMATIK ANTARA SISWA YANG DIBERI PEMBELAJARAN KOOPERATIF TIPE THINK-TALK-WRITE DENGAN PEMBELAJARAN LANGSUNG
}

\author{
Putri Maisyarah Ammy1, Ismail Hanif Batubara² \\ ${ }^{1,2}$ Dosen Program Studi Pendidikan Matematika FKIP Universitas Muhammadiyah Sumatera Utara \\ putrimaisyarah@umsu.ac.id ${ }^{1}$, ismailhanif@umsu.ac.id ${ }^{2}$
}

\begin{abstract}
The purposes of this study were to investigate: (1) Differences in mathematics conceptual understanding ability among students who are given a learning cooperative type Think-Talk-Write model with students who were given direct learning model. (2) To describe the active activity of student during learning cooperative type Think-Talk-Write. (3) To describe the accomplishing of student answers in learning cooperative type ThinkTalk-Write and direct learning. This was a semi-experimental study. The population was first grade students of SMP Muhammadiyah 1 Medan. Then randomly selected two classes of six grade. The experimental class ware given learning cooperative type ThinkTalk-Write model and control classes were subjected to direct teaching model. The instruments consisted of: (1) Mathematics conceptual understanding test, and (2) Observation sheet. Data analysis was performed by analysis of covariance (ANACOVA). The results showed that (1) There are differences in mathematics conceptual understanding among students who are given a model of learning cooperative type ThinkTalk-Write with students who were direct instruction model. This is evident from the results ANACOVA to $F_{\text {hitung }}=37,457$ is greater $F_{\text {tabel }} 4,01$. Constants of regression equations to model problem-based learning that is 27,027 greater than the direct learning model is 26,454. (2) The activity levels of active student has met the ideal percentage of time set. (3) the completing of students answers that are taught by learning cooperative type Think-Talk-Write model are better than students whorm are taught by using direct instruction model.
\end{abstract}

Keywords: Think-Talk-Write, Mathematics Conceptual Understanding

\begin{abstract}
Abstrak. Tujuan dari penelitian ini untuk mengetahui: (1) Perbedaan kemampuan pemahaman konsep matematik antara siswa yang diberi model pembelajaran kooperatif tipe Think-Talk-Write dengan model pembelajaran langsung. (2) Mendeskripsikan kadar aktivitas aktif siswa selama proses pembelajaran kooperatif tipe Think-Talk-Write. (3) Mendeskripsikan proses penyelesaian jawaban siswa pada pembelajaran kooperatif tipe Think-Talk-Write dan siswa yang diberikan pembelajaran langsung. Penelitian ini merupakan penelitian semi eksperimen. Populasi penelitian ini adalah siswa kelas VII SMP Muhammadiyah 1 Medan. Kemudian secara acak dipilih dua kelas dari enam kelas. Kelas eksperimen diberi perlakuan model pembelajaran kooperatif tipe Think-Talk-Write dan kelas kontrol diberi perlakuan model pembelajaran langsung. Instrumen yang digunakan teridi dari, (1) Tes kemampuan pemahaman konsep dan (2) Lembar observasi siswa. Analisis data dilakukan dengan analisis kovarian (ANACOVA). Hasil penelitian menunjukkan bahwa (1) Terdapat perbedaan kemampuan pemahaman konsep matematik antara siswa yang diberi model pembelajaran kooperatif tipe Think-Talk-Write dengan model pembelajaran langsung. Hal ini terlihat dari hasil ANACOVA untuk $F_{\text {hitung }}=$ $37,457>F_{\text {tabel }}=4,01$. Konstanta persamaan regresi untuk model antara siswa yang diberi model pembelajaran kooperatif tipe Think-Talk-Write, yaitu 27,027 lebih besar dari model pembelajaran langsung, yaitu 26,454. (2) Kadar aktivitas aktif siswa telah memenuhi waktu persentase ideal yang telah ditetapkan. (3) Proses penyelesaian jawaban siswa yang pembelajarannya dengan menggunakan model pembelajaran kooperatif tipe Think-Talk-Write lebih baik dibandingkan dengan model pembelajaran langsung.
\end{abstract}

Kata Kunci: Think-Talk-Write, Kemampuan Pemaham Konsep Matematik 


\section{PENDAHULUAN}

Pendidikan adalah salah satu bentuk perwujudan kebudayaan manusia yang dinamis dan sarat perkembangan. Oleh karena itu, perubahan atau perkembangan pendidikan adalah hal yang memang seharusnya terjadi dan sejalan dengan perubahan budaya kehidupan. Perubahan dalam arti perbaikan pendidikan pada semua tingkat ters-menerus dilakukan sebagai antisipasi kepentingan masa depan.

Pendidikan yang mampu mendukung pembangunan di masa mendatang adalah pendidikan yang mampu mengembangkan potensi siswa, sehingga yang bersangkutan mampu menghadapi dan memecahkan problema kehidupan yang dihadapinya. Konsep pendidikan terus semakin terasa pentingnya ketika seseorang memasuki dunia kerja dan di masyarakat, karena yang bersangkutan harus mampu menerapkan apa yang dipelajari di sekolah untuk menghadapi problema yang dihadapi dalam kehidupan sehari-hari saat ini maupun yang akan datang.

Salah satu aspek kompetensi yang diharapkan adalah kemampuan pemahaman konsep matematik. Kemampuan dasar matematika menurut Sumarmo (2006) dapat diklasifikasikan dalam lima standar kemampuan, yaitu (1) mengenal, memahami dan menerapkan konsep, prosedur, prinsip, dan ide matematik; (2) menyelsaikan masalah matematika; (3) bernalar matematik; (4) melakukan koneksi matematik; dan (5) komunikasi matematik.

Untuk dapat memenuhi hubungan antara bagian matematika, anatara satu konsep dengan konsep lainnya, harus saling terkait karena kemampuan pemahaman konsep siswa pada topik tertentu menuntut pemahaman konsep pada topik sebelumnya. Oleh karena itu, dalam belajar matematika siswa harus memahami terlebih dahulu makna dan penurunan konsep, prinsip, hukum, aturan, dan kesungguhan yang diperoleh.

Namun kenyataan di lapangan menunjukkan bahwa hasil pembelajaran matematika dalam aspek pemahaman konsep matematik masih rendah. Guru masih belum memanfaatkan pemahaman konsep sebagai target dalam pembelajaran matematika. Siswa seringkali tidak memahami makna yang sebenarnya dari suatu permasalahan. Mereka hanya mempelajari prosedur mekanistik yang diperlukan untuk menyelesaikan masalah itu.

Dalam NCTM (2000) dikatakan bahwa: "Pemahaman konsep matematik, merupakan aspek yang sangat penting dalam prinsip pembelajaran matematika". Siswa dalam belajar matematika harus disertai dengan pemahaman konsep, hal ini merupakan visi dari belajar matematika. Dinyatakan pula, bahwa belajar tanpa pemahamn konsep merupakan hal yang terjadi dan menjadi masalah sejak tahun 1930an, sehingga belajar dengan pemahaman konsep tersebut terus ditekankan dalam kurikulum.

Menurut Sanjaya (2006) mengatakan bahwa: "Pemahaman konsep adalah kemampuan siswa yang berupa penguasaan sejumlah materi pelajaran, dimana siswa tidak sekedar mengetahui atau mengingat sejumlah konsep yang dipelajari, tetapi mampu mengungkapkan kembali dalam bentuk lain yang mudah dimengerti, memberikan interprestasi data dan mampu mengaplikasikan konsep yang sesuai dengan struktur kognitif yang dimilikinya. Jadi, pemaham konsep merupakan dasar dari pemahaman prinsip dan teori, sehingga untuk dapat memahami prinsip dan teori harus dipahami terlebih dahulu konsep-konsep yang menyusun prinsip dan teori tersebut. 
Apabila siswa telah memahami konsep, artinya konsep tersebut sudah tersimpan dalam pikirannya berdasarkan pola-pola tertentu yang dibutuhkan oleh siswa untuk ditetapkan dalam pikiran mereka sendiri sebagai ciri dari kesan mental untuk membuat suatu contoh konsep dan membedakan contoh dari non contoh dari konsep. Konsep matematika abstrak memungkinkan kita untuk dapat mengelompokkan (mengklasifikasi) objek atau kejadian tersebut untuk dapat menyatakan contoh atau bukan contoh dari konsep.

Aktivitas belajar siswa hanya menjadi pendengar saja, jawaban siswa yang benar diterima, sedikit tanya jawab, siswa mencatat dari papan tulis, dan mengerjakan latihan yang hasilnya ditulis di papan tulis, sehingga seringkali siswa tidak mampu menjawab soal yang berbeda dari cantoh yang diberikan guru.

Pentingnya pemahaman konsep matematik dikuasai oleh siswa, namun kenyataannya di lapangan bahwa kemampuan pemahaman konsep matematik masih kurang maksimal, terutama dalam pokok bahasan yang dianggap sulit oleh siswa. Kebanyakan siswa terbiasa melakukan kegiatan belajar berupa menghafal tanpa dibarengi pengembangan pemahaman konsep matematik. Kemampuan ini diperlukan siswa sebagai bekal dalam memecahkan matematika dan masalah yang ditemukan dalam kehidup sehari-hari.

Untuk menumbuhkembangkan kemampuan pemahaman konsep matematik dalam pembelajaran matematika, guru harus mengupayakan pembelajaran dengan menggunakan model pembelajaran atau model pembelajaran kooperatif yang dapat memberi peluang dan mendorong siswa untuk melatih kemampuan pehaman konsep matematik siswa, karena setiap siswa mempunyai kemampuan yang berbeda dalam memahami matematika.

Model pembelajaran yang diduga dapat meningkatkan kemampuan pemahaman konsep matematik siswa adalah model pembelajaran kooperatif. Dalam pembelajaran kooperatif, siswa akan lebih aktif, karena terjadi proses diskusi atau interaksi antara siswa dalam kelompoknya. Melalui kegiatan diskusi, percakapan dalam mengungkapkan ide-ide matematika dapat membantu siswa mengembangkan pikirannya, sehingga siswa terlibat dalam perbedaan pendapat atau mencari solusi dari suatu permasalahan akan memahami konsep matematik dengan lebih baik.

Ada banyak model pembelajaran kooperatif yang bisa kita gunakan dalam upaya meningkatkan kemampuan pemahaman konsep matematik, salah satu upaya yang dapat dilakukan untuk mengatasi masalah-masalah tersebut adalah dengan menerapakan model pembelajaran kooperatif tipe Think-Talk-Write. Pembelajaran kooperatif tipe Think-Talk-Write merupakan salah satu alternatif pembelajaran yang dapat meningkatkan kemampuan pemahaman konsep matematik siswa. Pembelajaran kooperatif tipe Think-Talk-Write mempunyai kelebihan, yaitu pada tahap atau alur pembelajaran ini dimulai dari keterlibatan siswa dalam berpikir, berbicara, dan membagi ide dengan temannya sebelum menulis, sehingga model pembelajaran kooperatif tipe Think-Talk-Write ini diharapkan dapat meningkatkan kemampuan pemahaman konsep matematik siswa.

Berdasarkan latar belakang di atas, maka perlu untuk mengungkapkan apakah pembelajaran kooperatif tipe Think-Talk-Write dan pembelajaran langsung memiliki perbedaan kontribusi terhadap kemampuan pemahaman konsep matematik siswa. Hal itulah yang mendorong dilakukan penelitian yang memfokuskan dari pada penerapan model pembelajaran kooperatif tipe Think-Talk-Write terhadap kemampuan pemahaman konsep matematik siswa SMP dengan judul: "Perbedaan Kemampuan 
Pemahaman Konsep Matematika Antara Siswa Yang Diberi Pembelajaran ThinkTalk-Write Dengan Pembelajaran Langsung”.

\section{METODE}

Penelitian ini menggunakan pendekatan kualitatif dengan metode eksperimen dalam bentuk jenis quasi eksperimen. Penelitian eksperimen menurut Sugiyono (2010) diartikan sebagai metode penelitian yang digunakan untuk mencari pengaruh perlakuan tertentu terhadap yang lain dalam kondisi yang terkendali. Penelitian ini mencakup tiga tahapan, yaitu tahapan persiapan, tahap pelaksanaan, dan tahap analisa data serta penulisan laporan. Instrumen yang digunakan untuk mengumpulkan data dalam penelitian ini, terdiri dari tes kemampuan pemahaman konsep matematik, lembar pengamatan aktivitas siswa, dan proses penyelesaian jawaban siswa. Berkaitan dengan pertanyaan penilitian dan proses penyelesaian siswa dianalisis dengan analisis statistik deskriptif dan data hasil belajar dianalisis dengan statistik inferensial. Teknik analisis data deskriptif meliputi data kemampuan pemahaman konsep matematik, data aktivitas siswa, dan data proses jawaban siswa, sedangkan teknik analisis data inferensial menggunakan ANACOVA yang meliputi uji normalitas, uji homogenitas, menentukan model regresi, uji idenpendensi X terhadap Y, uji linearitas model regresi, uji kesamaan dua model regresi, dan uji kesejajaran dua model regresi.

\section{HASIL DAN PEMBAHASAN}

\section{Hasil}

Penelitian ini diperlukan analisis dan interpretasi data hasil penelitian dengan menggunakan analisis statistik deskripsi dan analisis statistik inferensial. Analisis statistik deskripsi digunakan untuk menganalisi kadar aktivitas aktif siswa dalam eksperimen pembelajaran dan proses penyelesaian jawaban siswa dalam mengerjakan tes awal dan tes akhir. Sedangkan analisis statistik inferensial digunakan untuk menguji hipotesis dalam penelitian ini dengan menganalisis data hasil belajar sebelum pembelajaran dan sesudah eksperimen pembelajaran.

\section{Analisis Deskriptif Kemampuan Pemahaman Konsep Matematik}

Tes kemampuan pemahaman konsep matematik dilakukan dua kali, yaitu tes awal dan tes akhir dengan soal yang berbeda. Tes awal dan tes akhir diikuti oleh 30 orang siswa.

Tabel 1. Ketuntasan Hasil Tes Awal dan Tes Akhir Kemampuan Pemahaman Konsep Matematik

\begin{tabular}{ccccc}
\hline \multirow{2}{*}{ Jenis Tes } & \multirow{2}{*}{ No } & \multirow{2}{*}{ Aspek } & \multicolumn{2}{c}{ Kelompok } \\
\cline { 2 - 5 } & 1 & Proporsi skor tes awal & 47,63 & 50,83 \\
\cline { 2 - 5 } Pemahaman & 2 & Proporsi skor tes akhir & 55,37 & 71,67 \\
\cline { 2 - 5 } $\begin{array}{c}\text { Konsep } \\
\text { Matematik }\end{array}$ & 3 & $\begin{array}{c}\text { Jumlah siswa yang } \\
\text { tuntas }\end{array}$ & 4 & 25 \\
\cline { 2 - 5 } & 4 & \% Ketuntasan & 13,33 & 83,33 \\
\hline
\end{tabular}

Pada tabel di atas dapat dilihat, kemampuan pemahaman konsep matematik skor tes awal dan tes akhir siswa kelas kontrol adalah 47,63 dan 55,37, terjadi peningkatan skor sebesar 7,74. Sedangakan kelas ekperimen skor tes awal dan tes akhir adalah 
50,83 dan 71,67, terjadi peningkatan skor sebesar 20,84. Selisih skor tes awal dan tes akhir kelas eksperimen lebih besar selisihnya dari skor tes awal dan tes akhir kelas kontrol. Hal ini memberi petunjuk bahwa eksperimen dapat meningkatkan pencapaian kemampuan pemahaman konsep matematik dari pada kontrol.

\section{Analisis Deskriptif Kadar Aktivitas Aktif Siswa}

Persentase dari rata-rata aktivitas aktif siswa dalam pembelajaran untuk setiap kategari aktivitas aktif siswa selama empat kali pertemuan dirangkum pada tabel di bawah ini:

Tabel 2. Kadar Aktivitas Siswa Selama Kegiatan Pembelajaran di Kelas Eksperimen

\begin{tabular}{|c|c|c|c|c|c|c|c|}
\hline \multirow[t]{2}{*}{ No } & \multirow{2}{*}{$\begin{array}{c}\text { Kategori } \\
\text { Pengamatan }\end{array}$} & \multicolumn{4}{|c|}{$\begin{array}{c}\text { Kadar Aktivitas Siswa / } \\
\text { Pertemuan }(\%)\end{array}$} & \multirow{2}{*}{$\begin{array}{c}\text { Rata- } \\
\text { rata }(\%)\end{array}$} & \multirow[t]{2}{*}{ Batas Toleransi } \\
\hline & & I & II & III & IV & & \\
\hline 1 & Mendengarkan & 25,5 & 23,4 & 26,6 & 29,7 & 26,3 & $20 \% \leq \mathrm{PWI} \leq 30 \%$ \\
\hline 2 & Membaca & 10,3 & 14,2 & 15,6 & 12,5 & 13,1 & $10 \% \leq \mathrm{PWI} \leq 20 \%$ \\
\hline 3 & Menulis & 25,2 & 23,4 & 26,6 & 29,7 & 26,2 & $25 \% \leq \mathrm{PWI} \leq 35 \%$ \\
\hline 4 & Berdiskusi & 26,3 & 25,4 & 27,5 & 30 & 27,3 & $25 \% \leq \mathrm{PWI} \leq 35 \%$ \\
\hline 5 & Persentase & 7,2 & 8,5 & 6,2 & 9,2 & 7,8 & $5 \% \leq \mathrm{PWI} \leq 15 \%$ \\
\hline 6 & $\begin{array}{l}\text { Perilaku siswa yang } \\
\text { tidak relevan dengan } \\
\text { KBM pembelajaran }\end{array}$ & 1,5 & 1,5 & 2,4 & 3,3 & 2,2 & $0 \% \leq \mathrm{PWI} \leq 5 \%$ \\
\hline
\end{tabular}

Sesuai dengan kreteria yang ditentukan dalam penelitian, dimana 5 dari 6 kategori pengamatan aktivitas aktif siswa telah memenuhi batas toleransi yang ditentukan, sehingga aktivitas aktif siswa berada pada batas toleransi yang ditentukan.

\section{Analisis Keragaman Proses Penyelesaian Jawaban Siswa}

Proses penyelesaian masalah siswa dianalisis secara deskriptif. Menurut Ruseffendi (1993) mengatakan bahwa: "Statistik deskriptif merupakan tingkat pengerjaan statistika yang berkenaan dengan pengumpulan data, pengolahaan data, penganalisis dan penyajian sebagian atau seluruh data tanpa pengambilan kesimpulan. Dari hasil post tes siswa kelas model pembelajaran kooperatif tipe Think-Talk-Write dan kelas model pembelajaran langsung dianalisis proses penyelesaian siswa. Proses jawaban atau kinerja siswa dilihat dari skor maksimal dari tiap-tiap indikator kemampuan pemahan konsep matematik. Berdasarkan lembar jawaban siswa dalam menjawab setiap soal yang dikategorikan dalam aspek-aspek pemahaman konsep matematik, yaitu (1) menuliskan konsep dengan bahasa sendiri; (2) membuat contoh serta non contoh; dan (3) menggunakan konsep untuk menyelesaikan soal cerita, bahwasannya siswa sudah bisa menjawab soal dengan benar sesuai dengan aspekaspek di atas, walaupun ada beberapa siswa yang menjawab soal dengan sesuka hati mereka, baik di kelas eksperimen maupun di kelas kontrol.

\section{Analisis Inferensial Kemampuan Pemahaman Konsep Matematik}

Analisis inferensial tes hasil kemampuan pemahaman konsep matematik siswa ditunjukkan untuk menguji hipotesis, kemampuan pemahaman konsep matematik anatara siswa yang diberi eksperimen dengan siswa yang diberi kontrol. Sebelum digunakan statistik ANACOVA, harus memenuhi uji normalitas, uji homogenitas, menentukan model regresi, uji idenpendensi X terhadap Y, uji linearitas model regresi, uji kesamaan dua model regresi, dan uji kesejajaran dua model regresi. 


\section{a. Uji Normalitas}

Pengujian ini dilakukan untuk melihat apakah data hasil tes pemahaman konsep berdistribusi secara normal pada kelompok kontrol dan kelompok eksperimen. Dari hasil perhitungan tes kemampuan awal pemahaman konsep matematik siswa pada kelas kontrol diperoleh: $L_{\text {hitung }}=0,1269$ dan $L_{\text {tabel }}=\frac{0,886}{\sqrt{30}}=0,1617$. Ternyata $L_{\text {hitung }} \leq$ $L_{\text {tabel }}$ artinya data berdistrubusi normal. Sedangkan untuk tes kemampuan awal pemahaman konsep matematik siswa pada kelas eksperimen diperoleh: Lhitung $=0,0601$ dan $L_{\text {tabel }}=\frac{0,886}{\sqrt{30}}=0,1617$. Ternyata $L_{\text {hitung }} \leq L_{\text {tabel }}$ artinya data berdistribusi normal. Dari hasil perhitungan tes akhir untuk pemahaman konsep matematik siswa pada kelas kontrol diperoleh: $L_{\text {hitung }}=0,1348$ dan $L_{\text {tabel }}=\frac{0,886}{\sqrt{30}}=0,1617$. Ternyata $L_{\text {hitung }} \leq L_{\text {tabel }}$ artinya data berdistrubusi normal. Sedangkan tes akhir pemahaman konsep matematik siswa pada kelas eksperimen diperoleh: $L_{\text {hitung }}=0,1158$ dan $L_{\text {tabel }}=\frac{0,886}{\sqrt{30}}=0,1617$. Ternyata $L_{\text {hitung }} \leq L_{\text {tabel }}$ artinya data berdistribusi normal.

\section{b. Uji Homogenitas}

Uji homogenitas adalah pengujian sama tidaknya variabel-variabel dua buah distribusi atau lebih. Pengujian homogenitas ini menggunakan uji varians dua buah peubah bebas. Varians tes kemampuan awal pemahaman konsep matematik di kelas eksperimen $\left(S_{E}^{2}\right)=21,178$ dan variansi tes kemampuan awal kelas kontrol $\left(S_{K}^{2}\right)=$ 25,964. Maka diperoleh: $F_{\text {hitung }}=\frac{S_{\text {besar }}^{2}}{S_{\text {kecil }}^{2}}=\frac{21,178}{25,964}=0,82$ dan $F_{\text {tabel }}=1,84$, dengan $v_{1}$ $($ pembilang $)=(30-1), v_{2}$ (penyebut $)=(30-1)$ dan taraf signifikan $(\alpha)=5 \%$, karena $F_{\text {hitung }}<F_{\text {tabel }}$, maka $\mathrm{H}_{0}$ diterima artinya data tes kemampuan awal pemahaman konsep adalah homogen. Untuk tes akhir pemahaman konsep di kelas eksperimen $\left(S_{E}^{2}\right)=$ 97,954 dan variansi tes kemampuan awal kelas kontrol $\left(S_{K}^{2}\right)=63,206$. Maka diperoleh: $F_{\text {hitung }}=\frac{S_{\text {besar }}^{2}}{S_{\text {kecil }}^{2}}=\frac{97,954}{63,206}=1,55$ dan $F_{\text {tabel }}=1,84$, dengan $v_{1}$ (pembilang $)=(30$ $-1), v_{2}$ (penyebut $)=(30-1)$ dan taraf signifikan $(\alpha)=5 \%$, karena $F_{\text {hitung }}<F_{\text {tabel }}$, maka $\mathrm{H}_{0}$ diterima artinya data tes kemampuan awal pemahaman konsep adalah homogen.

\section{c. Model Regresi}

Dari data hasil uji awal dan uji akhir siswa diperoleh persamaan regresi untuk kelas kontrol adalah $\mathrm{Y}_{\mathrm{K}}=26,454+0,607 \mathrm{X}_{\mathrm{K}}$ dan persamaan regresi untuk kelas eksperimen adalah $\mathrm{Y}_{\mathrm{E}}=27,027+0,878 \mathrm{X}_{\mathrm{E}}$.

\section{d. Uji Idenpendensi Tes Awal Terhadap Tes Akhir}

Untuk kelas kontrol diperoleh $\mathrm{F}^{*}=4,99$ dan berdasarkan tabel $\mathrm{F}$, untuk $\alpha=5 \%$ diperoleh $\mathrm{F}_{(1-\alpha ; 1, \mathrm{n}-2)}=\mathrm{F}_{(0,95 ; 1,28)}=4,20$. Berarti $\mathrm{F}^{*} \geq \mathrm{F}_{(0,95 ; 1,28)} . \mathrm{H}_{0}$ ditolak dan $\mathrm{H}_{1}$ diterima. Artinya ada pengaruh positif hasil uji awal kemampuan pemahaman konsep matematik terhadap hasil uji akhir siswa untuk kelas kontrol. Sedangkan untuk kelas eksperimen diperoleh $\mathrm{F}^{*}=5,60$ dan berdasarkan tabel $\mathrm{F}$, untuk $\alpha=5 \%$ diperoleh $\mathrm{F}_{(1-}$ $\alpha ; 1, n-2)=\mathrm{F}_{(0,95 ; 1,28)}=4,20$. Berarti $\mathrm{F}^{*} \geq \mathrm{F}_{(0,95 ; 1,28)}$. $\mathrm{H}_{0}$ ditolak dan $\mathrm{H}_{1}$ diterima. Artinya ada pengaruh positif hasil uji awal kemampuan pemahaman konsep matematik terhadap hasil uji akhir siswa untuk kelas kontrol 


\section{e. Uji Linearitas Model Regresi}

Pada kelas kontrol diperoleh $\mathrm{F}^{*}=0,17$ dan berdasarkan tabel $\mathrm{F}$, untuk $\alpha=5 \%$ diperoleh $\mathrm{F}_{(1-\alpha, \mathrm{c}-2 ; \mathrm{n}-\mathrm{c})}=\mathrm{F}_{(0,95 ; 9,19)}=2,42$. Berarti $\mathrm{F}^{*}<\mathrm{F}_{(0,95 ; 9,19)} . \mathrm{H}_{0}$ diterima atau model regresi kelas kontrol adalah linier. Artinya ada hubungan antara hasil tes awal dengan tes akhir siswa kelas kontrol. Sedangkan kelas eksperimen diperoleh $\mathrm{F}^{*}=0,92$ dan berdasarkan tabel $\mathrm{F}$, untuk $\alpha=5 \%$ diperoleh $\mathrm{F}_{(1-\alpha, \mathrm{c}-2 ; \mathrm{n}-\mathrm{c})}=\mathrm{F}_{(0,95 ; 12,16)}=2,42$. Berarti $\mathrm{F}^{*}$ $<\mathrm{F}_{(0,95 ; 12,16)}$. $\mathrm{H}_{0}$ diterima atau model regresi kelas eksperimen adalah linier. Artinya ada hubungan antara hasil tes awal dengan tes akhir siswa kelas eksperimen.

\section{f. Uji Kesamaan Dua Model Regresi}

Dari hasil perhitungan yang diperoleh untuk kemampuan pemahaman konsep $\mathrm{F}^{*}$ $=724,02$ berdasarkan Tabel $\mathrm{F}$, untuk $\alpha=5 \%$ diproleh $\mathrm{F}_{(1-\alpha ; 2, \mathrm{n}-2)}=\mathrm{F}_{(0,95 ; 2,58)}=3,16$. Berarti $\mathrm{F}^{*} \geq \mathrm{F}_{(0,95 ; 2,58)}$. $\mathrm{H}_{0}$ ditolak dan diterima $\mathrm{H}_{1}$. Hal ini berarti bahwa kedua model regresi linier tersebut adalah tidak sama atau berbeda secara signifikan.

\section{g. Uji Kesejajaran Dua Model Regresi}

Dari hasil perhitungan yang diperoleh untuk kemampuan pemahaman konsep diperoleh nilai $\mathrm{F}^{*}=3,79$ dan berdasarkan Tabel $\mathrm{F}$, untuk $\alpha=5 \%$ diproleh $\mathrm{F}_{(1-\alpha ; 1, \mathrm{n}-2)}=$ $\mathrm{F}_{(0,95 ; 1,58)}=4,01$. Berarti $\mathrm{F}^{*}<\mathrm{F}_{(0,95 ; 1,58)}$, makaa $\mathrm{H}_{0}$ diterima dengan taraf signifikan $5 \%$. Hal ini berarti bahwa kedua model regresi linier untuk kelas kontrol dan kelas eksperimen adalah sejajar. Oleh karena kedua model regresi tidak sama (tidak berimpit) dan sejajar, maka dapat disimpulkan bahwa ada perbedaan hasil belajar kelompok eksperimen dan kelompok kontrol.

\section{h. Analisis Kovarians dengan Modifikasi Analisis Varians}

Berdasarkan hasil uji linieritas dan kesejajaran model regresi dipenuhi, maka untuk menguji perbedaan kemampuan pemahaman konsep matematik siswa yang diajar dengan pembelajaran kooperarif tipe Think-Talk-Write dengan kemampuan pemahaman konsep matematik siswa yang diajar dengan pembelajaran langsung dapat dianalisis dengan ANACOVA sebagai modifikasi analisis varians. Untuk itu dirumuskan hipotesis analisisnya dengan menduga jarak kedua garis regresi linier kelompok kontrol dan kelompok eksperimen dari setiap skor hasil tes akhir dari ratarata skor tes akhir kelompok kontrol dan skor tes akhir dari kelompok eksperimen. Hipotesisnya adalah sebagai berikut:

$$
\begin{aligned}
& \mathrm{H}_{0}: \theta_{2}=\theta_{4} \\
& \mathrm{H}_{1}: \theta_{2}>\theta_{4}
\end{aligned}
$$

Keterangan:

$\theta_{2}$ : Kemampuan pemahaman konsep matematik yang diajar dengan pembelajaran TTW

$\theta_{4}$ : Kemampuan pemahaman konsep matematik yang diajar dengan pembelajaran Langsung

Dari hasil perhitungan untuk kemampuan pemahaman konsep diperoleh $\mathrm{F}^{*}=$ $\frac{M S T_{(a d j)}}{M S E_{(a d j)}}=\frac{1555,553}{41,529}=37,457$ dan berdasarkan Tabel $\mathrm{F}$, untuk $\alpha=5 \%$ diperoleh $\mathrm{F}_{(0,95}$, 1,58) $=4,01$. Berarti $F^{*} \geq F_{(0,95,1,58)}$, sehingga $\mathrm{H}_{0}: \theta_{2}=\theta_{4}=0$ ditolak. Hal ini berarti ada perbedaan yang signifikan antara kemampuan pemahaman konsep siswa yang dikenai perlakuan eksperimen dengan siswa yang dikenai kontrol. 
Tabel 3. Rangkuman Hasil Pengujian Hipotesis Penelitian Kemampuan Pemahaman Konsep Matematik pada Taraf Signifikan 5\%

\begin{tabular}{clc}
\hline No & \multicolumn{1}{c}{ Hipotesi Penelitian } & Hasil Pengujian \\
\hline $\mathbf{1}$ & $\begin{array}{l}\text { Ada pengaruh positif (signifikansi) hasil tes kemampuan awal } \\
\text { pemahaman konsep siswa terhadap hasil tes akhir siswa untuk } \\
\text { kelas kontrol. }\end{array}$ & Ditolak \\
\hline $\mathbf{2}$ & $\begin{array}{l}\text { Hasil tes kemampuan awal pemahaman konsep siswa terhadap } \\
\text { hasil tes akhir siswa untuk kelas kontrol memiliki model regresi } \\
\text { linier. }\end{array}$ & Diterima \\
\hline $\mathbf{3}$ & $\begin{array}{l}\text { Model regresi kelompok eksperimen dan model regresi kelompok } \\
\text { kontrol adalah tidak sama atau berbeda secara signifikan untuk } \\
\text { kemampuan pemahaman konsep. }\end{array}$ & Ditolak \\
\hline $\mathbf{4}$ & $\begin{array}{l}\text { Model regresi kelompok eksperimen dan model regresi kelompok } \\
\text { kontrol adalah sejajar (tidak berimpit) untuk kemampuan } \\
\text { pemahaman konsep. }\end{array}$ & Diterima \\
\hline $\mathbf{5}$ & $\begin{array}{l}\text { Ada perbedaan yang signifikan antara kemampuan pemahaman } \\
\text { konsep matematika siswa yang dikenai perlakuan eksperimen dan } \\
\text { siswa yang dikenai kontrol. }\end{array}$ & Ditolak \\
\hline
\end{tabular}

\section{Pembahasan}

Pada bagian ini akan diuraikan deskripsi dan interpretasi terhadap kemampuan pemahaman konsep matematik, aktivitas aktif siswa, dan proses penyelesaian jawaban siswa dalam menyelesaikan masalah yang diberikan pada pembelajaran koopertif tipe Think-Talk-Write dan pembelajaran langsung.

Melihat hasil penelitian yang telah dikemukakan di atas, menunjukkan bahwa pembelajaran koopertif tipe Think-Talk-Write secara signifikan lebih baik dalam meningkatkan kemampuan pemahaman konsep matematik siswa dibandingkan dengan pembelajaran langsung. Jika kita perhatikan karekteristik pembelajaran dari kedua pendekatan tersebut adalah suatu hal yang wajar terjadinya perbedaan tersebut. Secara teoritis pembelajaran koopertif tipe Think-Talk-Write memiliki beberapa keunggulan jika dibandingkan dengan pembelajaran langsung yang apabila keunggulan-keunggulan ini dimaksimalkan dalam pelaksanaan di kelas sangat memungkinkan proses pembelajaran menjadi lebih baik.

Seperti telah dikemukakan sebelumnya, bahwa yang dimaksud dengan kemampuan pemahaman konsep matematik adalah kemampuan siswa menuliskan konsep dengan bahasa sendiri, membuat contoh serta non contoh dari konsep, dan mengaplikasikan konsep ke pemecahan masalah. Hasil penelitian menunjukkan, pencapaian ketuntasan hasil kemampuan pemahaman konsep dan siswa dengan pembelajaran koopertif tipe Think-Talk-Write jauh lebih besar daripada kelas yang dikenai pengajaran langsung. Ketuntasan belajar tercapai pada kelas eksperimen, yaitu terdapat 25 orang siswa dari 30 orang siswa atau 83,33\%. Sedangkan pada kelas kontrol terdapat 4 orang siswa dari 30 orang siswa atau 13,33\%.

Model pembelajaran koopertif tipe Think-Talk-Write secara signifikan telah berhasil meningkatkan kemampuan pemahaman konsep matematika siswa jika dibandingkan dengan model pembelajaran langsung. Hasil penelitian dilihat dari konstanta persamaan regresi untuk model pembelajaran koopertif tipe Think-TalkWrite, yaitu 27,027 sedangkan model pembelajaran langsung 26,454.

Aspek melakukan perhitungan, ada beberapa soal yang dikerjakan siswa dengan lengkap, ada juga yang salah dalam melakukan perhitungan (penjumlahan dan 
pembagian). Untuk mencari penyelesaian masalah (jawaban) para siswa harus mampu memanfaatkan pengetahuan mereka. Penyelesaian akhir (jawaban) bukanlah tujuan akhir dari pembelajaran matematika, melainkan sebagai bagian terbesar dari aktivitas ini (Turmudi, 2008). Dari penelitian ini jumlah siswa yang menuliskan penyelesaian masalah secara lengkap dan benar pada model pembelajaran koopertif tipe Think-TalkWrite sebanyak 25 siswa sedangkan pada model pembelajaran langsung sebanyak 4 siswa. Variasi jawaban di kelas eksperimen lebih banyak dibandingkan dengan kelompok kontrol.

Dari hasil analisis deskriptif data aktivitas aktif siswa dan berdasarkan kriteria yang ditetapkan diperoleh kesimpulan bahwa aktivitas siswa dalam pembelajaran koopertif tipe Think-Talk-Write adalah efektif. Aktivitas siswa dalam pembelajaran koopertif tipe Think-Talk-Write adalah banyaknya aktivitas yang dilakukan siswa selam proses belajar mengajar dan diamati dengan instrument lembar observasi aktivitas siswa. Aktivitas siswa yang dimaksud meliputi: mendengarkan atau memperhatikan penjelasan guru atau teman, membaca LAS, mencatat dari apa yang dibaca, berdiskusi dengan kelompok, dan mempersentasekan hasil kerja kelompok.

Kadar aktivitas siswa dapat dijelaskan bahwa kadar aktivitas siswa kategori pengamatan "Mendengarkan", persentase waktu idealnya adalah 26,3\%. Kadar aktivitas aktif siswa kategori pengamatan "Membaca", persentase waktu idealnya adalah 13,1\%. Kadar aktivitas aktif siswa kategori pengamatan "Menulis", persentase waktu idealnya adalah 26,3\%. Kadar aktivitas aktif siswa kategori pengamatan "Berdiskusi", persentase waktu idealnya adalah 27,3\%. Kadar aktivitas aktif siswa kategori pengamatan "Persentase", persentase waktu idealnya adalah 7,8\%. Kadar aktivitas aktif siswa kategori pengamatan "Prilaku siswa yang tidak relevan dengan KBM Pembelajaran", persentase waktu idealnya adalah 2,2\%.

Aktivitas siswa selama pembelajaran koopertif tipe Think-Talk-Write terlihat aktif dan kreatif, serta memiliki semangat yang tinggi dalam setiap pembelajaran yang diberikan. Ditinjau dari cirri-ciri belajar pembelajaran koopertif tipe Think-Talk-Write adalah suatu strategi pembelajaran yang dimulai dengan berpikir melalui bahan bacaan (menyimak, mengkritisi, dan alternatif solusi), hasil bacaannya dikomunikasikan dengan presentasi, diskusi, dan kemudian buat laporan hasil presentasi.

\section{KESIMPULAN}

Berdasarkan hasil analisis data dan temuan penelitian selama model pembelajaran kooperatif tipe Think-Talk-Write dengan menekankan pada kemampuan pemahaman konsep matematik, maka peneliti memperoleh kesimpulan sebagai berikut:

1. Terdapat perbedaan kemampuan pemahaman konsep matematik antara siswa yang diberi model pembelajaran kooperatif tipe Think-Talk-Write dengan siswa yang diberi model pembelajaran langsung.

2. Kadar aktivitas aktif siswa telah memenuhi waktu persentase ideal yang telah ditetapkan

3. Proses penyelesaian jawaban siswa dengan mengunakan model pembelajaran kooperatif tipe Think-Talk-Write lebih baik dibandingkan dengan model pembelajaran langsung. Hal ini ditunjukkan dengan jawaban siswa dalam menyelesaikan tes kemampuan pemahaman konsep matematik lebih baik pada kelas model pembelajaran kooperatif tipe Think-Talk-Write dibandingkan dengan model pembelajaran langsung. 


\section{DAFTAR PUSTAKA}

NCTM (National Council of Teachers of Mathematics). (2000). Principles and Standards for School Mathematics. Reston, VA: NCTM.

Ruseffendi, E. T. (1993). Statistik Dasar untuk Penelitian Pendidikan. Bandung: IKIP Bandung Press.

Sanjaya, W. (2006). Stratrgi Pembelajaran Berorientasi Standar Proses Pendidikan. Jakarta: Kencana Prenada Media.

Sugiyono. (2010). Metode Penelitian Pendidikan. Bandung: Alfabeta.

Sumarmo, U. (2006). Pembelajaran Keterampilan Membaca Matematika pada Siswa Sekolah Menengah. Bandung: FMIPA UPI

Turmudi. (2008). Landasan Filsafat dan Teori Pembelajaran Matematika (Berparadigma Eksploratif dan Investigasi). Jakarta: Leuser Cita Pustaka. 